\title{
The control of herbage intake in the grazing ruminant
}

\author{
By J. Hodgson, Hill Farming Research Organization, Bush Estate, Penicuik, \\ Midlothian $\mathrm{EH}_{2} 6$ oPY
}

The effects of variations in the nutrient content and internal structure of plant tissues on the voluntary intake of forages by ruminants have been extensively reviewed (e.g. Freer, 198r) and explained in terms of conventional theories of metabolic and physical controls to appetite (Bines, 1971; Baile \& Forbes, 1974). The same controls are undoubtedly of importance for grazing as well as for housed animals (Freer, I 981 ), but they do not take into account the potential influence of non-nutritional characteristics of vegetation on herbage intake under grazing conditions. In this respect several authors have emphasized the important influence of variations in the amount of herbage on offer either per unit area or per animal (see Hodgson, $1981 a$ ), and in the structure of the sward canopy (Johnstone-Wallace \& Kennedy, 1944; Stobbs, I973a), with particular reference to the importance of behavioural limitations in the control of herbage intake (Allden, 1962). McClymont (1967) provided an important conceptual framework within which to examine the possible interactions between metabolic, physical and behavioural controls under grazing conditions, but an understanding of the mechanisms involved has been slow to develop. The objective in this review is to consider the evidence on (a) the interrelations between the components of ingestive behaviour and their impact on herbage intake, and (b) the causal relations between the structural characteristics of the sward canopy and grazing activity.

\section{Ingestive behaviour and herbage intake}

Initially the justification for arguments about behavioural limitations to herbage intake rested on the demanding nature of the food-gathering process in grazing animals (Johnstone-Wallace \& Kennedy, 1944) and much of the early evidence, though convincing, was circumstantial. However, more critical evidence was provided by Chacon \& Stobbs (1976) who demonstrated limitations to the ability of cattle to compensate for the removal of digesta from the rumen by increasing grazing activity.

Allden \& Whittaker (1970), following Allden (1962), postulated a view of the herbage intake of grazing animals $(I)$ as the product of the time spent grazing $(G T)$, the rate of biting during grazing $(R B)$ and the weight of herbage consumed per grazing bite $(I B)$, thus:

$$
I=I B \times R B \times G T .
$$

This somewhat mechanistic concept has provided the basis for most subsequent investigations of the influence of behavioural responses on the relations between sward characteristics and herbage intake, and the same approach is followed here. 
Intake per bite, $I B$, is the variable most directly influenced by sward conditions, and normally falls sharply as herbage mass or sward height declines (Allden \& Whittaker, 1970). The rate of biting, $R B$, usually tends to increase with declining $I B$, but the rate of increase is seldom fast enough to prevent an associated decline in the short-term rate of herbage intake $(I B \times R B$ ) (Allden \& Whittaker, 1970; Hodgson, $198 \mathrm{I} b$ ). Increase in $R B$ has been seen as a compensatory response by the animal to offset declining $I B$. However, it appears to be due primarily to a reduction in the number of manipulative jaw movements required on shorter swards and a consequent increase in the ratio, biting: manipulative movements
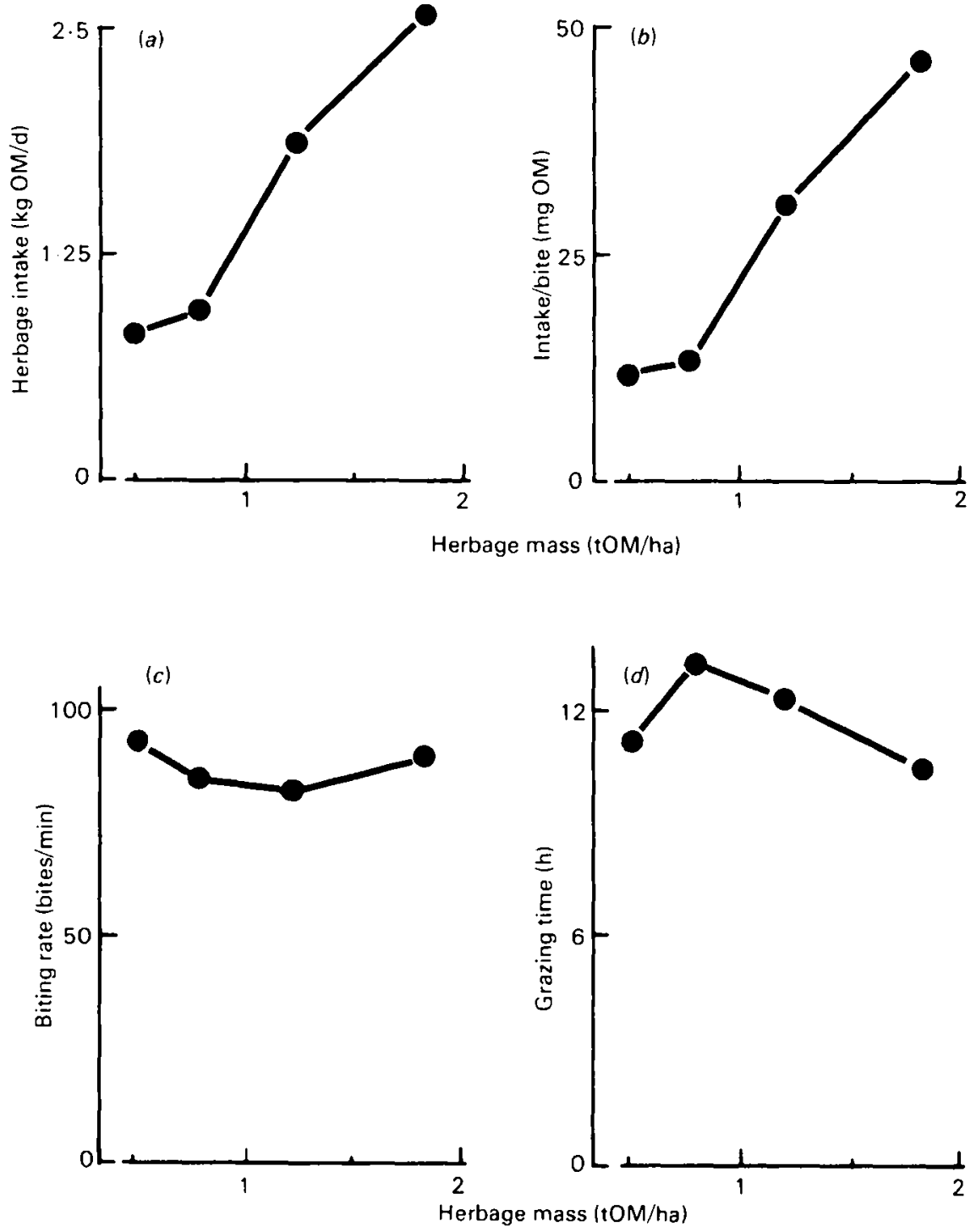

Fig. I. The influence of variations in herbage mass on (a) daily herbage intake (kg organic matter $(\mathrm{OM})$ ), (b) intake per bite ( $\mathrm{mg} \mathrm{OM}$ ), (c) rate of biting (bites/min) and (d) grazing time in ewes grazing continuously-stocked swards (from Bircham, 198r). 
(Table I), and should therefore be considered as a direct effect of variation in sward conditions.

The most readily apparent adaptive response is the increase in $G T$ which usually occurs when the rate of intake declines (Freer, 198I). However, the degree of compensation is again limited, so that variations in daily herbage intake frequently reflect closely the observed variations in $I B$. Indeed, $G T$ may actually decline on particularly short swards, reinforcing the effect of depression in $I B$. The relative magnitude of the responses of the components of ingestive behaviour to variations in sward conditions, and their combined influence on daily herbage intake, are illustrated in Fig. 1.

\section{Ingestive behaviour and sward characteristics}

In many grazing studies attention has been concentrated on the influence of gross sward variables like total herbage mass or surface height on ingestive behaviour and herbage intake (Hodgson, 1977). However, the empirical relations derived from these studies are of limited value in providing an appreciation of the control processes involved (Freer, 1981). Understanding of causation requires a greater knowledge of the components of sward canopy structure and their influence on the mechanics of the grazing process.

In a typical sward in a vegetative stage of growth the upper horizons of the canopy are made up primarily of living leaf laminae, whereas the leaf sheaths

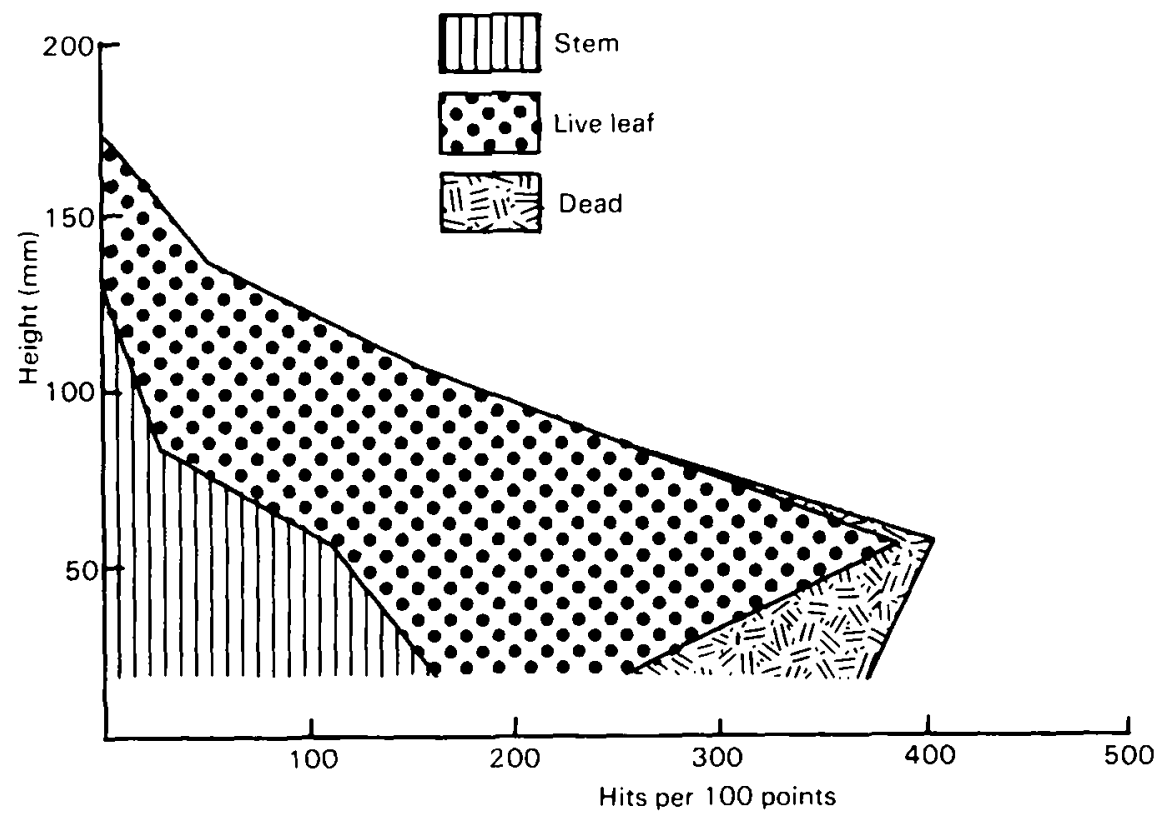

Fig. 2. The vertical distribution of plant material within the canopy of a perennial ryegrass (Lolium perenne)-white clover (Trifolium repens) sward. Values on the horizontal axis represent the number of contacts within $30 \mathrm{~mm}$ strata per 100 traverses of a point quadrat needle, and therefore provide a measure of the bulk density of herbage within successive strata (from Forbes, 1982). 
(aggregated into pseudostems) and dead tissue are concentrated in the lower horizons. In swards at a more advanced stage of maturity, true stems are distributed throughout the canopy (Fig. 2). Barthram \& Grant (1984) have shown that sheep readily graze within the leafy horizons of a vegetative sward, but are reluctant to penetrate into the lower horizons containing pseudostem and dead material. Thus the depth of the leafy horizon sets an effective limit to the depth of a bite (i.e. the vertical distance between the surface of the sward canopy and the severed ends of leaves). This limit appears to be reached for sheep in swards with a leaf horizon less than 20-30 $\mathrm{mm}$ deep (Barthram \& Grant, I984), but in swards with a deeper leaf horizon there is a roughly proportional relation between sward surface height and bite depth (Milne et al. I982; Barthram \& Grant, I984).

There is less information on which to postulate a basis for control of the number of leaves or stems prehended and, hence, on the area covered per bite. In normal temperate swards the basis for control may involve behavioural adaptation to limit the force required to sever each bite of herbage (Hughes, I983) in response to variations in the structural strength of plant tissue. Substance is lent to this suggestion by the evidence (Chambers et al. I $98 \mathrm{I}$ ) that variations in the rate of acceleration of the head during biting are relatively small, both within and between swards, in sheep and cattle (Table 1 ). It is probable that shearing strength (Hendricksen \& Minson, I980) is more important than tensile strength (Evans, 1967) in determining the resistance of plant tissue to defoliation by grazing animals. On particularly sparse swards the number of leaves and stems prehended at a bite is more likely to be limited by the maximum area encompassed by the lips or tongue in sheep and cattle respectively, though this view will be influenced by the extent to which plants are distributed in a clumped fashion.

This evidence provides a basis for understanding the influence of sward structure and morphology on the dimensions of individual bites of herbage. Herbage intake per bite may then be considered as the product of bite volume

Table $\mathrm{I}$. The influence of variations in sward height on rate of biting (bites/min), number of jaw movements per bite and rate of head acceleration during biting $\left(\mathrm{m} / \mathrm{s}^{2}\right)$ in grazing sheep and cattle (from Chambers et al. 1981)

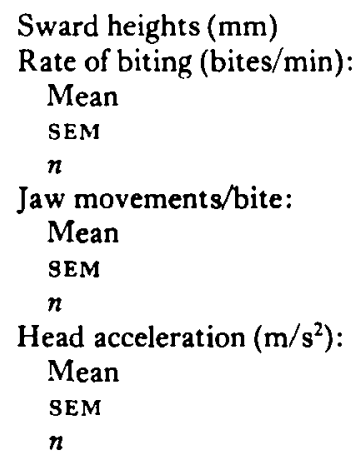

\begin{tabular}{|c|c|c|c|}
\hline \multicolumn{2}{|c|}{ Sheep } & \multicolumn{2}{|c|}{ Cattle } \\
\hline 40 & 120 & 90 & I 50 \\
\hline 52 & 26 & 53 & $4^{6}$ \\
\hline $3 \cdot 7$ & $1 \cdot 6$ & $2 \cdot 9$ & $3 \cdot 7$ \\
\hline 32 & 32 & 25 & 21 \\
\hline I 7 & 3.0 & $1 \cdot 2$ & $1 \cdot 7$ \\
\hline 0.08 & 0.17 & 0.05 & 0.18 \\
\hline 209 & 132 & 219 & 203 \\
\hline $8 \cdot 8$ & $7 \cdot 5$ & $4 \cdot 7$ & $5 \cdot 2$ \\
\hline 0.12 & 0.15 & 0.09 & 0.12 \\
\hline 239 & 133 & 216 & 211 \\
\hline
\end{tabular}


(depth $\times$ area) and the bulk density (weight per unit volume) of herbage within the sward horizons encompassed in a bite. However, bulk density and height are usually negatively correlated both within (Fig. 2) and between swards, and this complicates the interpretation of observations on the relation between bulk density and $I B$. Variations in $I B$ appear to be attributable more to variations in sward height than density in temperate swards (Hodgson, $198 \mathrm{I} b$ ), but the reverse is the case in tropical swards (Stobbs, 1973a). Stobbs (1973b) explained this contrast in terms of the generally lower bulk density and greater height of tropical than of temperate swards, but the ranges of variation in height and density in the swards used in the two sets of studies were in fact similar. Black \& Kenney (1984), working with artificial swards, showed that $I B$ increased in response to increases in either sward height or herbage bulk density when the two were controlled independently, despite a concomitant decline in bite area in both cases. Further critical work of this kind should help to resolve some of the apparent conflicts in the results of field studies.

To summarize, there is now a basis for understanding the influence of plant morphology and sward structure on herbage intake in terms of variation in the physical dimensions of individual bites of herbage, the bulk density of herbage within the volume encompassed at a bite, and the rate of biting. This view of grazing activity is most easily applied in the case of uniform swards in a vegetative or early reproductive stage of growth, in which animals graze largely indiscriminately from the surface horizons and where individual bites can be ascribed relatively simple dimensions. It also appears to be applicable, however, to more mature or complex swards in which animals discriminate actively between different plant species or morphological units (Forbes, I982), though in these cases it may be necessary to consider bite dimensions in terms of individual leaves. Discrimination between leaf and stem may itself be related to differences in shearing strength (Hendricksen $\&$ Minson, 1980 ), and the process of diet selection carries with it implications to herbage intake in terms of reductions in $I B$ and $R B$ (Stobbs, 1973a,b).

\section{Animal effects on ingestive behaviour}

Cattle and sheep exhibit similar diurnal patterns of grazing activity, and biting rates and grazing times are similar in the two species (Arnold, 1981). Variations in physiological state can have a marked impact on ingestive behaviour. Thus, both grazing time and rate of intake may be substantially higher in lactating than in non-lactating animals, and thin animals have higher rates of intake than fat animals, though the relative magnitude of these effects appears to differ in different circumstances (Arnold, 198 $\mathrm{r}$ ).

In general terms, patterns of response in ingestive behaviour or herbage intake to variations in sward structure appear to be similar for sheep and for cattle and, within species, for animals differing in age or productive state (Hodgson $1981 a$ ). Allden \& Whittaker (1970) showed that lambs were less sensitive to variations in tiller length than were yearling sheep, and suggested that small mouths would be 


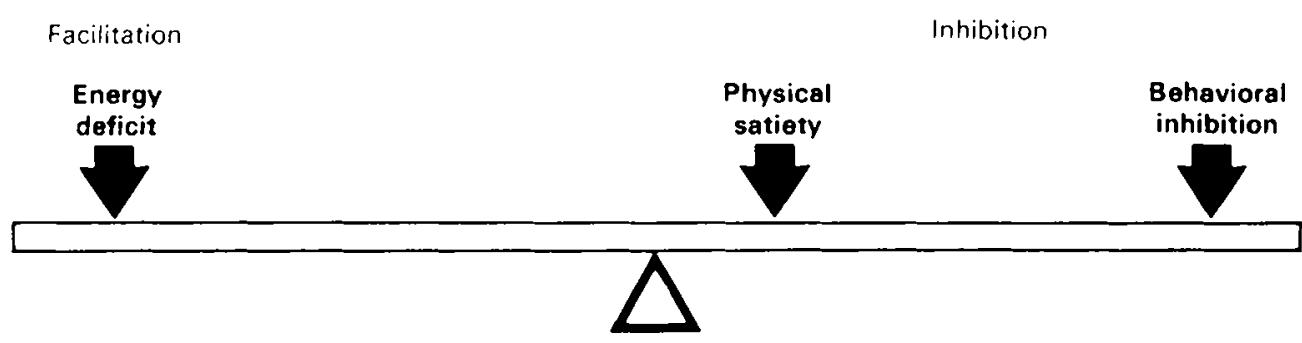

Fig. 3. A conceptual model of herbage intake (McClymont, 1967).

an advantage to animals grazing short swards, whereas large mouths would be an advantage in tall swards. A similar argument has been used in the context of inter-specific differences in mouth size and structure and body size (Schwartz \& Ellis, $198 \mathrm{I}$ ), but direct evidence on the sensitivity of sheep and cattle to declining herbage mass or sward surface height is equivocal (e.g. Jamieson \& Hodgson, !979).

\section{The control of herbage intake}

Against the background of the arguments presented here, conceptual models of intake control in terms of 'threshold' or 'ceiling' theory seem inappropriate. Following McClymont ( $\mathrm{I}^{6} 67$ ) it would be more profitable to consider the control of herbage intake in grazing animals in terms of the balance struck between three sets of stimuli (Fig. 3), representing:

I. A facilitatory feeding drive, reflecting the current balance between nutrient 'demand' and supply. 'Demand' is a somewhat difficult concept in the case of animals which are most likely to respond to nutrient intake on the basis of a series of production functions, but might be defined as the nutrients required to meet the genetic potential for body tissue deposition, lactation or wool growth, in addition to the maintenance of body function, at a particular point in time. This balance is most easily viewed in terms of energy, but other nutrients may be implicated.

In this sense the feeding drive would substitute for, and subsume, the concept of chemostatic intake controls (Baile $\&$ Forbes, 1974) which in any case appear to be of very limited importance in productive ruminants on all-forage diets (Hodgson, 1977; Freer, 1981).

2. An inhibitory satiety response, reflecting the volume of digesta in the alimentary tract or the total volume of the organs in the abdominal cavity (Baile \& Forbes, 1974; Freer, 1981).

3. A limitation to behavioural adaptation which also acts as an inhibitory stimulus, reflecting (a) the ability of the animal to maintain the rate of herbage intake in the face of limiting sward conditions, and (b) its ability to modify grazing time in order to offset the effects of declining rate of intake. 
Metabolic and physical stimuli are clearly the dominant factors controlling forage intake in housed animals (Freer, $198 \mathrm{I}$ ) but behavioural inhibitions assume much greater importance under grazing conditions. It should be noted that this view of limitations to behavioural adaptability does not necessarily invoke the concept of fatigue (McClymont, 1967); the competing demands of other activities (e.g. rumination, drinking and social interactions) may also serve to limit grazing, particularly on a periodic basis (Freer, 1981). Though discussion has been concerned largely with herbage intake and ingestive behaviour on a day-by-day basis there is no reason why the same concepts should not apply to a consideration of individual periods of eating or grazing activity (McClymont, $x 967$; Forbes, 1980 ) or, indeed, to intake responses measured over longer time-intervals.

The inhibitory satiety stimulus and behavioural limitations may or may not reinforce one another, depending on sward conditions, and both appear to be sensitive to the magnitude of the perceived nutrient deficit. Thus, for example, the demands of lactation are likely to result in modifications to both grazing activity (Arnold, 198I) and the characteristics of the alimentary tract (Tulloh, I966).

Attention has been concentrated here on the three stimuli considered to be of dominant importance in influencing the feeding behaviour and herbage intake of grazing animals. McClymont ( 1967 ) postulated a number of additional facilitatory or inhibitory stimuli which he defined as adventitious (social factors, palatability, stress) but these factors, most of which will clearly be of importance in particular circumstances, are intermittent in impact and difficult to quantify.

\section{Conclusions}

There is a conceptual basis for understanding the causative relations between the structural characteristics of swards and the herbage intake of grazing animals, which should influence priorities in plant breeding and selection and in the management of swards and grazing animals. The need now is for objective definition of the patterns of response in ingestive behaviour and herbage intake to the manipulation of sward variables and, in particular, a clearer appreciation of the range of sensitivity to particular variables and their relative importance in specific circumstances. The slow development of understanding of the mechanisms involved has been due (a) to the limited ability to generalize from the large number of grazing studies involving the measurement of herbage intake, because of the limited information on sward structure and the difficulty of establishing the causative effects of particular sward variables, and (b) the difficulty of incorporating evidence on the influence of the components of ingestive behaviour into conventional concepts of the control of voluntary food intake because of the unwillingness of nutritionists to conduct critical studies outside the metabolism house. Neither of these limitations is insuperable (e.g. Stobbs, 1973a; Hodgson et al. 1977; Black \& Kenney, 1984). In view of the continuing national and world importance of livestock industries based on pastoral systems, there is a need for a more determined effort to provide a proper understanding of the scope for manipulating herbage intake under grazing conditions. 


\section{REFERENCES}

Allden, W. G. (1962). Proceedings of the Australian Society of Animal Production 4, 163-166.

Allden, W. G. \& Whittaker, I. A. McD. (1970). Australian Yournal of Agricultural Research 2 I, $755-766$.

Arnold, G. W. (1981). In Grazing Animals, pp. 79-104 [F. H. W. Morley, editor]. Amsterdam: Elsevier Scientific Publishing Company.

Baile, C. A. \& Forbes, J. M. (1974). Physiological Review 54, 160-214.

Barthram, G. T. \& Grant, S. A. (1984). Grass and Forage Science 39, 21 1-21 9.

Bines, J. (197I). Proceedings of the Nutrition Society 30, $116-122$.

Bircham, J. S. (198I). Herbage growth and utilisation under continuous stocking management. PhD Thesis, University of Edinburgh.

Black, J. L. \& Kenney, P. A. (1984). Australian fournal of Agricultural Research 35, 565-578.

Chacon, E. \& Stobbs, T. H. (1976). Australian Yournal of Agricultural Research 27, 709-727.

Chambers, A. R. M., Hodgson, J. \& Milne, J. A. (1981). Grass and Forage Science 36, 97-105.

Evans, P. S. (1967). Fournal of Agricultural Science, Cambridge 69, $171-174$.

Forbes, J. M. (1980). Appetite 1, 2 I-41.

Forbes, T. D. A. ( 1982$)$. Ingestive behaviour and diet selection in grazing cattle and sheep. PhD Thesis, University of Edinburgh.

Freer, M. (1981). In Grazing Animals, pp. 105-124 [F. W. H. Morley, editor]. Amsterdam: Elsevier Scientific Publishing Company.

Hendricksen, R. \& Minson, D. J. (1980). Journal of Agricultural Science, Cambridge 95, 547-554.

Hodgson, J. (1977). Proceedings of International Meeting on Animal Production from Temperate Grassland, pp. 70-74 [B. Gilsenan, editor]. Dublin: Irish Grassland and Animal Production Association/An Foras Taluntais.

Hodgson, J. (1981a). Proceedings of International Symposium, St Lucia, Queensland, Australia, August 24-28, 1981, pp. 153-166 [J. B. Hacker, editor]. Farnham Royal: Commonwealth Agricultural Bureaux.

Hodgson, J. ( $198 \mathrm{I} b$ ). Grass and Forage Science 36, 49-57.

Hodgson, J., Rodriguez Capriles, J. M. \& Fenlon, J. S. (1977). Fournal of Agricultural Science, Cambridge 89, 743-750.

Hughes, T. P. (1983). In Lamb Growth, pp. 65-78, Animal Industries Workshop, June-July 1983 [A. S. Familton, editor]. Canterbury, New Zealand: Lincoln College.

Jamieson, W. S. \& Hodgson, J. (1979). Grass and Forage Science 34, 273-282.

Johnstone-Wallace, D. B. \& Kennedy, K. (1944). Journal of Agricultural Science, Cambridge 34, 190-197.

McClymont, G. L. (1967). In Handbook of Physiology, Section 6, Alimentary Tract, vol. I, pp. 129-1 37 [Charles F. Code, editor]. Washington, DC: American Physiological Society.

Milne, J. A. Hodgson, J., Thompson, R., Souter, W. G. \& Barthram, G. T. (Ig82). Grass and Forage Science, 37, 209-218.

Schwartz, C. G. \& Ellis, J. E. (1981). Fournal of Applied Ecology 18, 343-353.

Stobbs, T. H. (1973a). Australian fournal of Agricultural Research 24, 809-8 9.

Stobbs, T. H. (1973b). Australian Fournal of Agricultural Research 24, $821-829$.

Tulloh, N. M. (1966). New Zealand Fournal of Agricultural Research 9·4, 999-1008. 